\title{
Individual milk fatty acids are potential predictors of enteric methane emissions from dairy cows fed a wide range of diets: Approach by meta-analysis
}

\author{
A. Bougouin, ${ }^{1}$ J. A. D. Ranga Niroshan Appuhamy, ${ }^{2}$ A. Ferlay, ${ }^{1}$ E. Kebreab, ${ }^{3}$ C. Martin, ${ }^{1}$ P. J. Moate,${ }^{4}$ \\ C. Benchaar, ${ }^{5}$ P. Lund, ${ }^{6}$ and $M$. Eugène ${ }^{1 *}$ \\ ${ }^{1}$ Université Clermont Auvergne, INRA, VetAgro Sup, UMR Herbivores, 63122 Saint-Genès-Champanelle, France \\ ${ }^{2}$ Department of Animal Science, lowa State University, Ames 50011 \\ ${ }^{3}$ Department of Animal Science, University of California, Davis 95616 \\ ${ }^{4}$ Agriculture Victoria Research, Ellinbank, Victoria 3821, Australia \\ ${ }^{5}$ Agriculture and Agri-Food Canada, Sherbrooke Research and Development Centre, Sherbrooke, Quebec, Canada J1M 0C8 \\ ${ }^{6}$ Department of Animal Science, Aarhus University, AU Foulum, DK-8830 Tjele, Denmark
}

\section{ABSTRACT}

There is a need to quantify methane $\left(\mathrm{CH}_{4}\right)$ emissions with alternative methods. For the past decade, milk fatty acids (MFA) could be used as proxies to predict $\mathrm{CH}_{4}$ emissions from dairy cows because of potential common rumen biochemical pathways. However, equations have been developed based on a narrow range of diets and with limited data. The objectives of this study were to (1) construct a set of empirical models based on individual data of $\mathrm{CH}_{4}$ emissions and MFA from a large number of lactating dairy cows fed a wide range of diets; (2) further increase the models' level of complexity (from farm to research level) with additional independent variables such as dietary chemical composition (organic matter, neutral detergent fiber, crude protein, starch, and ether extract), dairy performance (milk yield and composition), and animal characteristics (days in milk or body weight); and (3) evaluate the performance of the developed models on independent data sets including measurements from individual animals or average measurements of groups of animals. Prediction equations based only on MFA [C10:0, iso C17:0 + trans-9 C16:1,cis-11 C18:1, and trans-11,cis-15 $\mathrm{C} 18: 2$ for $\mathrm{CH}_{4}$ production (g/d); iso C16:0, cis-11 C18:1, trans-10 C18:1, and cis-9,cis-12 C18:2 for $\mathrm{CH}_{4}$ yield ( $\mathrm{g} / \mathrm{kg}$ of dry matter intake, DMI); and iso $\mathrm{C} 16: 0$, cis-15 C18:1, and trans-10 + trans-11 C18:1 for $\mathrm{CH}_{4}$ intensity ( $\mathrm{g} / \mathrm{kg}$ of milk)] had a root mean squared error of $65.1 \mathrm{~g} / \mathrm{d}, 2.8 \mathrm{~g} / \mathrm{kg}$ of DMI, and 2.9 $\mathrm{g} / \mathrm{kg}$ of milk, respectively, whereas complex equations

Received November 2, 2018.

Accepted June 20, 2019.

*Corresponding author: maguy.eugene@inra.fr that additionally used DMI, dietary neutral detergent fiber, ether extract, days in milk, and body weight had a lower root mean squared error of $46.6 \mathrm{~g} / \mathrm{d}, 2.6 \mathrm{~g} / \mathrm{kg}$ of DMI, and $2.7 \mathrm{~g} / \mathrm{kg}$ of milk, respectively). External evaluation with individual or mean data not used for equation development led to variable results. When evaluations were performed using individual cow data from an external data set, accurate predictions of $\mathrm{CH}_{4}$ production $(\mathrm{g} / \mathrm{d})$ were obtained using simple equations based on MFA. Better performance was observed on external evaluation with individual data for the simple equation of $\mathrm{CH}_{4}$ production ( $\mathrm{g} / \mathrm{d}$, based on MFA), whereas better performance was observed on external evaluation mean data for the simple equation of $\mathrm{CH}_{4}$ yield $(\mathrm{g} / \mathrm{kg}$ of DMI). The performance of evaluation of the models is dependent on the domain of validity of the evaluation data sets used (individual or mean).

Key words: dairy cow, methane emissions, prediction model, milk fatty acids

\section{INTRODUCTION}

Enteric methane $\left(\mathrm{CH}_{4}\right)$ emissions have been recognized as a major source of greenhouse gases in livestock farming. Dairy cow $\mathrm{CH}_{4}$ emissions account for $46 \%$ of the total greenhouse gas emissions in the world dairy supply chain when expressed as carbon dioxide $\left(\mathrm{CO}_{2}\right)$ equivalents (Gerber et al., 2013). The global demand for livestock products is constantly increasing (FAO, 2013). Ruminants are almost the sole source of milk for humans, providing 644 million tonnes per year of fat- and protein-corrected milk, of which dairy cattle contribute $80 \%$ (Gerber et al., 2013). The increasing demand for dairy products has led to the expansion of dairy herds. Therefore, there is a need for strategies to reduce $\mathrm{CH}_{4}$ emissions to limit the negative effect of 
dairy cows on the environment. Several dietary strategies, such as formulating diets rich in concentrate (and, more particularly, in starch) or supplementing diets with lipids or other chemical additives [3-nitrooxypropanol (3-NOP), nitrate, monensin; Odongo et al., 2007; Martin et al., 2010; Hristov et al., 2013], have proven their efficacy to reduce $\mathrm{CH}_{4}$ emissions from dairy cows. Methanogenesis is the main pathway that uses hydrogen $\left(\mathrm{H}_{2}\right)$, an unavoidable by-product resulting from dietary carbohydrate fermentation (48-80\%; Mills et al., 2001), whereas rumen biohydrogenation of UFA uses up to $3 \%$ of rumen $\mathrm{H}_{2}$ (Mills et al., 2001). Fermentation in the rumen also leads to the production of VFA, which are precursors for de novo synthesis of short- and medium-chain fatty acids (FA) in the mammary gland. In addition, certain VFA production pathways, such as acetate or butyrate, lead to production of $\mathrm{H}_{2}$, whereas propionate production pathway uses $\mathrm{H}_{2}$. Thus, direct interactions exist between rumen fermentation, $\mathrm{CH}_{4}$ production, and milk FA (MFA) composition.

Predictive tools such as empirical equations or mechanistic models for estimating $\mathrm{CH}_{4}$ emissions are useful for evaluating potential strategies for methane mitigation, especially because measurement techniques, such as open respiratory chambers or $\mathrm{SF}_{6}$ tracer technique, are costly and may be difficult to apply on large-scale dairy farms. Although numerous models have been developed to predict $\mathrm{CH}_{4}$ emissions from dairy cows based only on MFA (as reviewed in van Gastelen and Dijkstra, 2016) or with MFA and other variables such as milk production (Weill et al., 2008) or forage intake (Chilliard et al., 2009), the equations generally accurately predict $\mathrm{CH}_{4}$ emissions only for specific diets and situations similar to those under which the equations were developed. For example, the prediction equations presented by Chilliard et al. (2009) were developed using data from dairy cows consuming corn silage-based diets containing linseed. Furthermore, previous studies usually involved small numbers of dairy cows [e.g., 8 cows in Chilliard et al. (2009), 16 cows in Mohammed et al. (2011), 100 cows in Dijkstra et al. (2011), 146 cows in van Lingen et al. (2014), 32 cows in van Gastelen et al. (2017), and 218 cows in van Gastelen et al. (2018)].

The objectives of the present study were to (1) to construct a set of empirical models based on individual data of $\mathrm{CH}_{4}$ emissions and milk composition (MFA) from a large number of lactating dairy cows consuming a wide range of diets; (2) further increase the level of complexity (from research to farm level) of the developed models based on additional independent variables such as dietary chemical composition, production performance (milk yield and composition), and animal characteristics (DIM and BW); and (3) evaluate the performance of these models using independent data sets.

\section{MATERIALS AND METHODS}

\section{Databases and Variable Selection}

Individual Animal Data. The database was created using measurements made on individual animal data received from collaborators to develop prediction equations for $\mathrm{CH}_{4}$ based on MFA. For inclusion in the database, experiments must have met the following criteria: (1) $\mathrm{CH}_{4}$ production measured on individual dairy cows by means of respiration chambers, the $\mathrm{SF}_{6}$ tracer technique, or GreenFeed system; (2) MFA profiles of individual cows analyzed by GC (detailed description of the methods used to analyze the FA in milk was provided in each of the relevant cited papers); (3) measurements of daily DMI of individual cows; (4) measurements of dietary composition; (5) measurements of milk production and composition of individual cows; and (6) characteristics of individual cows (BW and DIM) recorded. Details of experiments used in the analysis are given in Supplemental Table S1 (https:// doi.org/10.3168/jds.2018-15940). Briefly, the data set contained 312 observations from published and unpublished experiments (17 experiments) by INRA-UMRH (Saint-Genès-Champanelle, France), 119 individual observations (5 experiments) from Aarhus University (Foulum, Denmark), 218 observations (7 experiments) from Ellinbank Research Centre (Australia), and 177 observations (5 experiments) from Agriculture and Agri-Food Canada. A total of 825 observations of $\mathrm{CH}_{4}$ emissions ( $\mathrm{g} / \mathrm{d}$ ) from individual lactating Holstein dairy cows and related DMI and diet chemical composition [OM, NDF, CP, starch, ether extract (EE)], animal characteristics (BW, DIM), milk performance (milk yield and milk composition: fat, protein, lactose, MFA), and $\mathrm{CH}_{4}$ mitigation treatments were obtained from the 34 in vivo experiments (15 randomized block and 19 Latin square designs). A wide range of dietary treatments was included in the data set. Main dietary forages were corn silage $(\mathrm{n}=297)$, grass silage $(\mathrm{n}=$ $157)$, or legume hay $(\mathrm{n}=157)$. Main concentrate ingredients included in the diets were rapeseed $(\mathrm{n}=264)$, corn grain $(\mathrm{n}=198)$, barley $(\mathrm{n}=124)$, and wheat $(\mathrm{n}=$ $83)$. The database included control diets $(\mathrm{n}=198)$ and $\mathrm{CH}_{4}$-mitigating treatments as described in Martin et al. (2010), including lipid supplementation $(\mathrm{n}=198)$, different forage or concentrate types (e.g., main forage of the diet, $\mathrm{n}=149$; main ingredient in the concentrate, $\mathrm{n}=140)$, probiotics $(\mathrm{n}=58)$, plant extract $(\mathrm{n}=33)$, 
and nitrate $(\mathrm{n}=16)$. Experiments are summarized in Supplemental Table S1 (https://doi.org/10.3168/jds .2018-15940). The data set gathered studies that tested lipid dose effects [mean EE of lipid-supplemented diets $=7 \pm 3.9 \%$ (SD) of DM], effects of lipid source (linseed, rapeseed, Ca salt of palm oil, sunflower, dry distillers grain with solubles; mean $\mathrm{EE}=5.5 \pm 0.8 \%$ of $\mathrm{DM}$; $\mathrm{n}=4$ experiments) or form (crushed, extruded, cake, oil; mean $\mathrm{EE}=6.0 \pm 0.4 \%$ of $\mathrm{DM} ; \mathrm{n}=1$ experiment), forage source effects (mean NDF $=35 \pm 6.4 \%$ of DM; $\mathrm{n}=7$ ), and the effect of different compositions of concentrate (starch rich, sugar rich, lipid rich, protein rich; mean starch $=23 \pm 9.9 \%$ of $\mathrm{DM} ; \mathrm{n}=6$ experiments) on $\mathrm{CH}_{4}$ emissions. In several experiments, various additives were tested for the effects of type or dose of additive on $\mathrm{CH}_{4}$ emissions. These included probiotics (4 experiments), tannins ( 2 experiments), lipid + calcium nitrate (2 experiments), saponin (2 experiments), and other plant extracts (3 experiments).

Milk FA fractions were expressed in grams per 100 grams of total MFA. Some studies reported coelution of different MFA, but no information regarding operating conditions (e.g., HPLC columns, temperatures) was provided by the authors. Thus, when these MFA were individually identified in other studies (e.g., iso C17:0 + trans-9 C16:1), they were grouped together. Furthermore, MFA with concentrations $<0.1 \mathrm{~g} / 100 \mathrm{~g}$ of total FA were not included in the data set.

The data set (34 experiments; $\mathrm{n}=825$ ) including the individual animal observations was randomly divided into 2 data sets: (1) a data set that contained $70 \%$ of experiments $(\mathrm{n}=24$, called the training data set) that was used to develop prediction models and (2) a data set that contained the remaining $30 \%$ of the experiments $(\mathrm{n}=10$, called the external individual data set) that was used to evaluate the robustness of the models (Tables 1 and 2).

Mean Database. Another database, called the external mean data set, was built with treatment means from the literature and was used to further evaluate the robustness of the models (Tables 1 and 2). A comprehensive literature search (up to January 2018) was conducted using Science Direct, CAB International, SCOPUS, and Web of Knowledge online databases with the following search terms: "methane" or "methane emission," "dairy," "cows" or "livestock" or "cattle," and "milk fatty acid." To be included in the data set, the studies were required to meet the same criteria used for selecting individual animal data. A total of 25 studies (Supplemental Table S2, https://doi.org/10 $.3168 /$ jds.2018-15940) were selected and used for model evaluation, and summary statistics are given in Tables 1 and 2. Briefly, the external mean data set included studies testing the effect of different dietary strategies on $\mathrm{CH}_{4}$ emissions as described in Martin et al. (2010): (1) lipid dose [mean $\mathrm{EE}=5 \pm 1.5 \%$ (SD) of $\mathrm{DM}]$; (2) lipid type or form; (3) forage type or level (mean $\mathrm{NDF}=37.68 \pm 1.326 \%$ of DM); (4) concentrate type or level (mean starch content $=20.7 \pm 7.6 \%$ of DM; mean percentage of concentrate $=35.7 \pm 13.4 \%)$; $(5)$ probiotics; (6) organic acids; (7) plant extracts; and (8) feed additives such as nitrate, monensin, and 3-NOP. There was no overlap among studies used to build the individual and mean data sets.

\section{Statistical Analyses}

Variable Preselection for Model Development. An exploratory data analysis was performed to evaluate the data for completeness (e.g., missing values of nutrient composition of diets), consistency in nomenclature of variables in question, and the presence of outliers (Pyle, 1999). When not measured, diet chemical composition, specifically NDF, starch, and EE, were estimated using feed composition tables in INRA (2007), NRC (2001), and Feedipedia (https://www.feedipedia .org/). Measured or calculated variables and their summary statistics are given in Tables 1 and 2. We detected outliers using the boxplot function in $\mathrm{R}$ (version 0.98.1102; R Foundation for Statistical Computing, Vienna, Austria). The outliers' values were compared with the range of reference values. When values were outside of this range, we requested further information from the data owner to understand this study effect or to decide to remove the data from further analyses ( $\mathrm{n}$ $=1$ ). The number of observations for each variable is provided in Tables 1 and 2.

Correlation Among Variables and Identification of Predictors. Data including observations (n $=825$ ) made on individual animals were used in this analysis. First, Pearson correlation coefficients were obtained for pairwise relationships among $\mathrm{CH}_{4}$ emissions and the individual MFA (concentration $>0.1 \mathrm{~g} / 100 \mathrm{~g}$ of MFA; $\mathrm{n}=46$ ) and to determine and select the most correlated individual MFA among the 5 MFA families (SFA, odd- and branched-chain FA, cis MUFA, trans MUFA, and PUFA). Milk FA missing for more than $50 \%$ of the observations were not considered in this analysis. Second, the Pearson correlation coefficients were obtained for each selected MFA within its family to determine how independent $(\mathrm{r} \leq 0.5)$ they were and thereby avoid potential collinearity in model development. Then, principal components analysis was performed using the "FactoMinR" and "MissMDA" packages (versions 1.34 and 1.7.3, respectively) in $\mathrm{R}$ (version 0.98.1102; R Foundation for Statistical Computing) on the MFA significantly associated with daily $\mathrm{CH}_{4}$ production $(\mathrm{g} / \mathrm{d} ; \mathrm{r} \geq|0.3|), \mathrm{CH}_{4}$ yield $(\mathrm{g} / \mathrm{kg}$ of 
MILK FATTY ACIDS AS PREDICTORS OF ENTERIC METHANE EMISSIONS

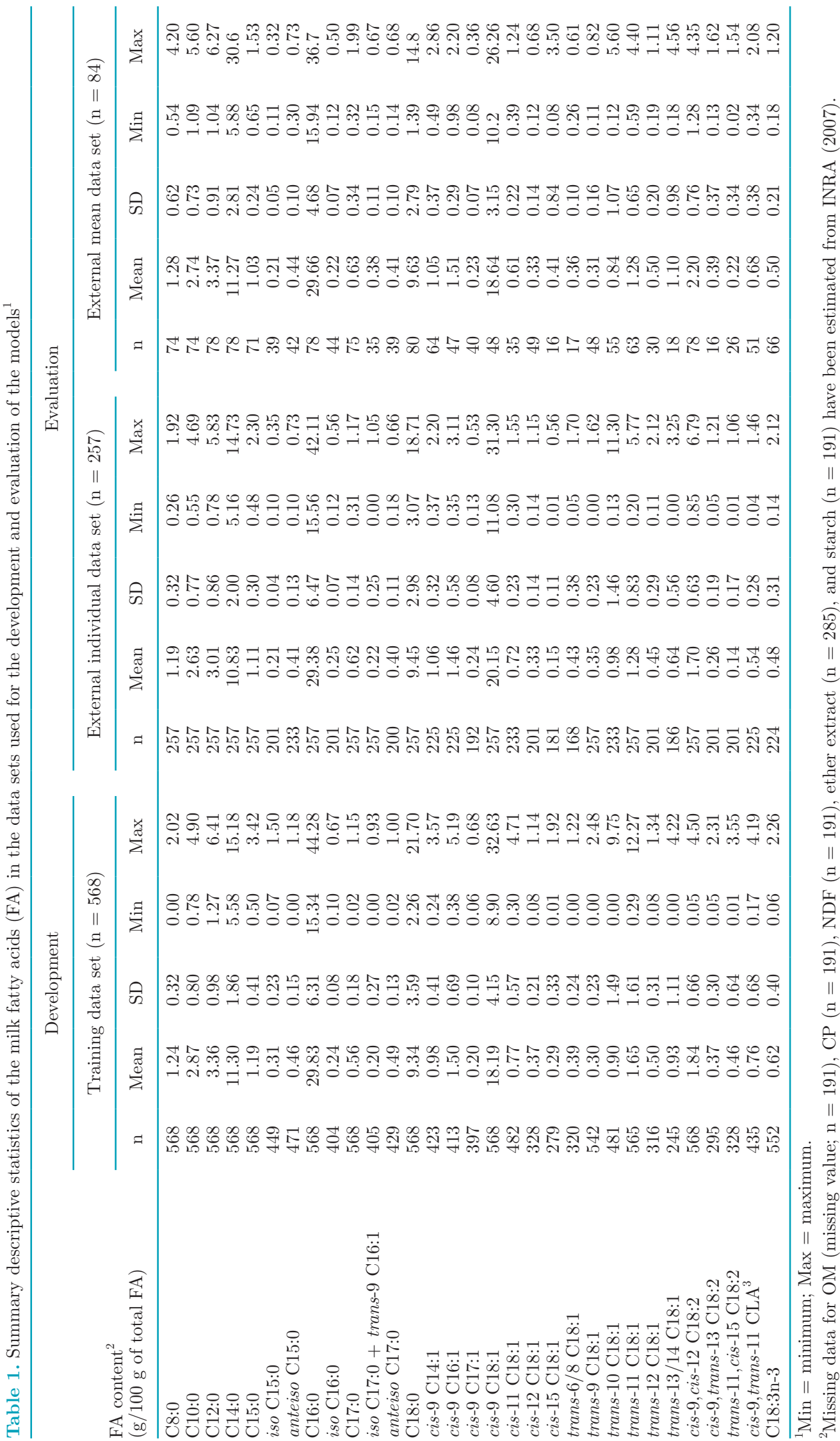


BOUGOUIN ET AL.

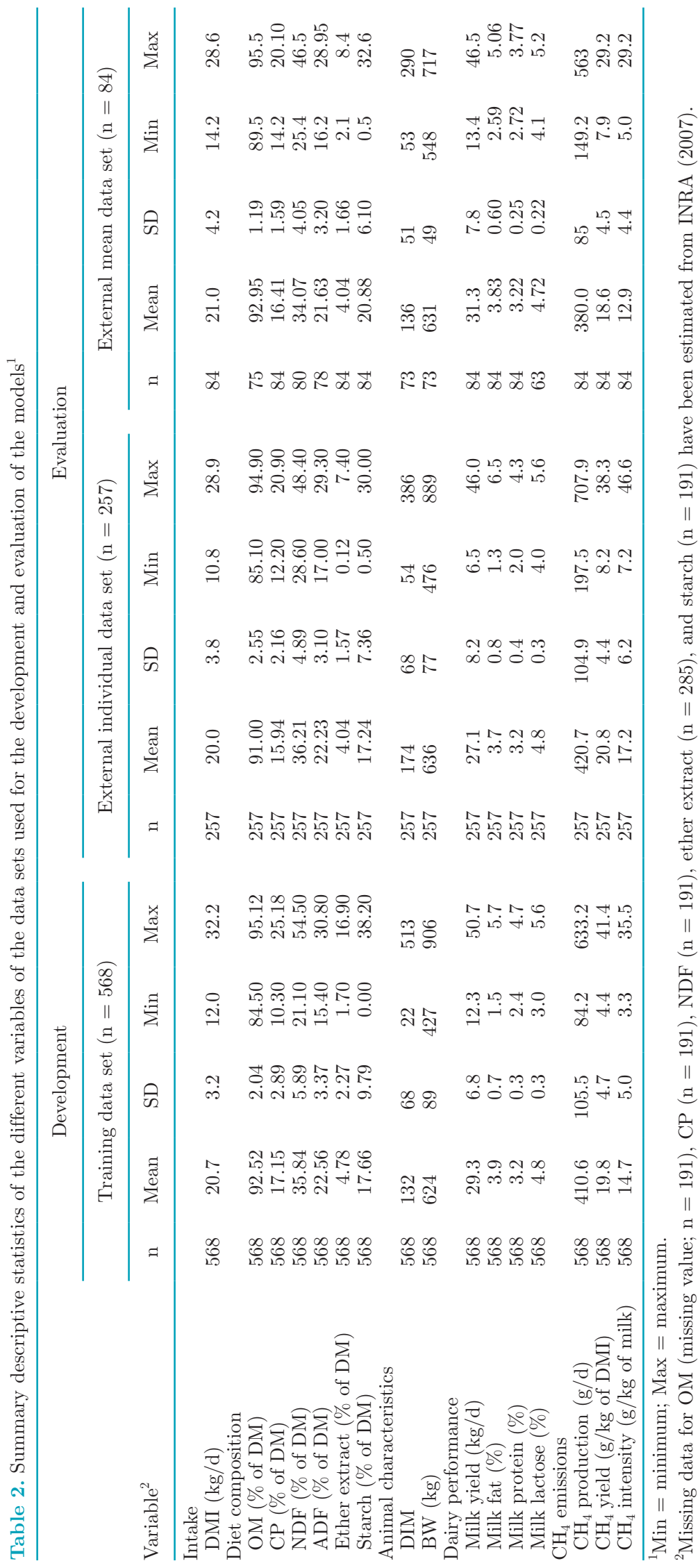




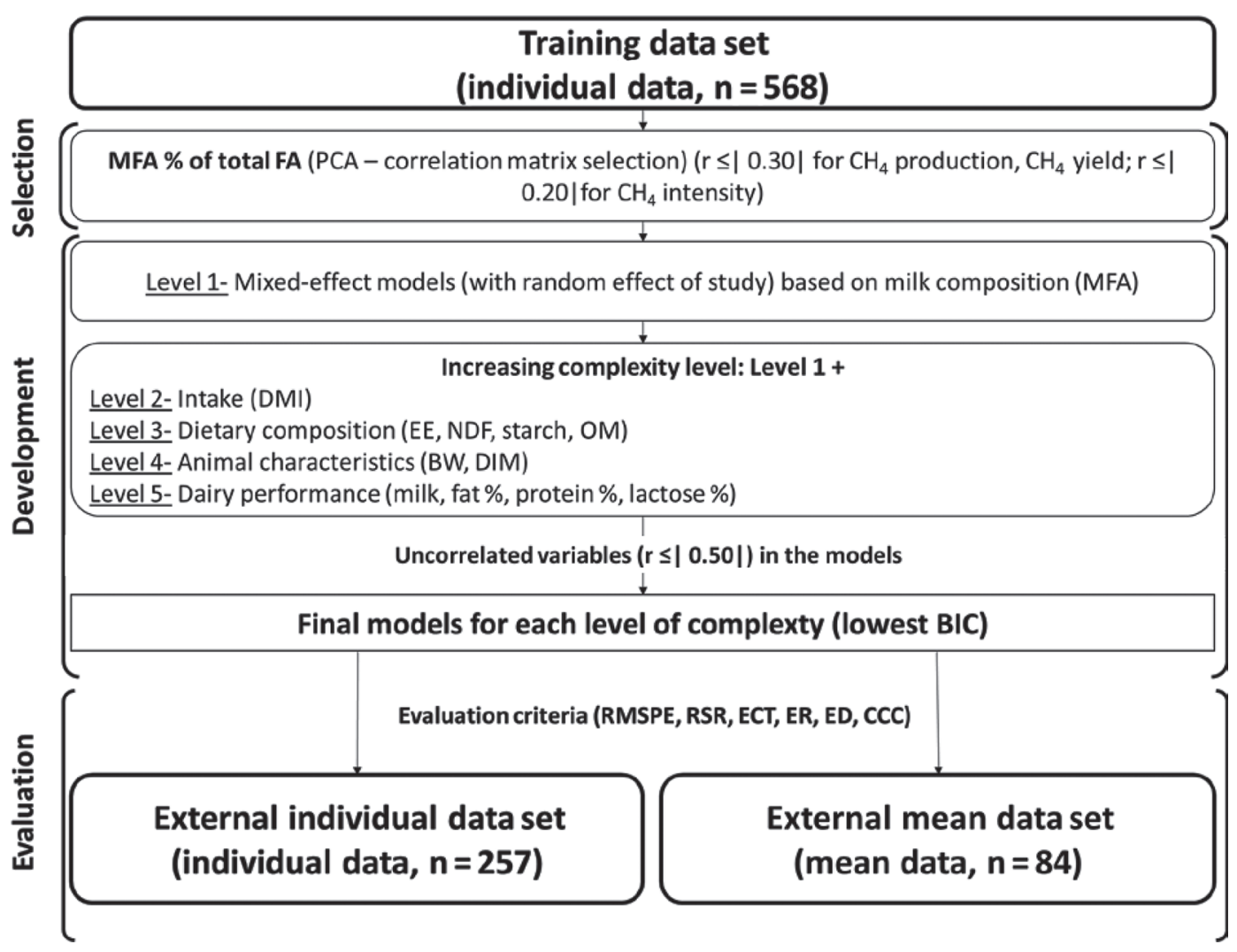

Figure 1. Diagram illustrating variable selection and model development and evaluation. MFA = milk fatty acid; FA = fatty acid; PCA $=$ principal component analysis; $\mathrm{CH}_{4}=$ methane; $\mathrm{EE}=$ ether extract; $\mathrm{BIC}=$ Bayesian information criteria; $\mathrm{RMSPE}=$ root mean squared prediction error; RSR = root mean squared deviation; $\mathrm{ECT}=$ error from mean bias; $\mathrm{ER}=$ error from regression linear bias; ED $=$ error from disturbance; $\mathrm{CCC}=$ concordance correlation coefficient.

DMI; $\mathrm{r} \geq|0.3|)$, and $\mathrm{CH}_{4}$ intensity $(\mathrm{g} / \mathrm{kg}$ of milk; $\mathrm{r} \geq$ $|0.2|)$ along with other variables to identify additional predictors of $\mathrm{CH}_{4}$ emissions.

Random-Effects Model Analysis. As mentioned, data from the entire data set $(\mathrm{n}=825)$ were obtained from randomly selected experiments divided ("dplyr" package in $\mathrm{R}$ ) into a training data set (24 experiments, $\mathrm{n}=568$ observations) for model development and another data set (hereafter called the external individual data set; 10 experiments, $\mathrm{n}=257$ ) for model evaluation. A set of linear mixed-effects models was constructed to separately predict $\mathrm{CH}_{4}$ production $(\mathrm{g} / \mathrm{d})$, yield $(\mathrm{g} / \mathrm{kg}$ of DMI), and intensity ( $\mathrm{g} / \mathrm{kg}$ of milk). Random-effect meta-analysis approaches (St-Pierre, 2001) were applied using the "nlme" package (version 3.1-131) in R (version 0.98.1102; R Foundation for Statistical Computing). The nlme function fits linear mixed-effects models in the framework described in Lindstrom and Bates (1990). Several models were developed with increasing level of complexity by incrementally adding different independent quantitative variables: dietary content (\% of DM) of CP, NDF, ADF, EE, and starch; BW (kg); DIM (d); milk yield (kg/d); and milk fat, protein, and lactose percentages. A first set of models began with the MFA that was most representative (in $\%$ of total FA) of each family selected based on pairwise correlations and principal components analysis. Then, DMI was added to the simplest models based on MFA, followed by milk performance, animal characteristics, or diet composition (Figure 1).

Finally, all significant variables were included together, carrying the same weight, to create highly complex models. Furthermore, this approach enabled analysis of fixed effects of independent variables such as MFA or DMI (Figure 1) as well as the study-specific deviation of the $\mathrm{CH}_{4}$ emission response, which was taken into account as a random effect. The general mixed-effect model for single and multiple regressions is represented as

$$
\mathrm{Y}=\beta_{0}+\beta_{1} \mathrm{X}_{1 \mathrm{ij}}+\beta_{2} \mathrm{X}_{2 \mathrm{ij}}+\ldots+\beta_{\mathrm{n}} \mathrm{X}_{\mathrm{nij}}+\mathrm{e}_{\mathrm{ij}},
$$

where $\beta_{0}, \beta_{1} X_{1 \mathrm{ij}}$, and $\beta_{2} \mathrm{X}_{2 \mathrm{ij}}, \ldots, \beta_{\mathrm{n}} \mathrm{X}_{\mathrm{nij}}$ are the fixed effects of independent variables (intercept and effects), and $\mathrm{e}_{\mathrm{ij}}$ is the random experiment effects $(\mathrm{i}=1, \ldots, \mathrm{n}$ studies and $\mathrm{j}=1, \ldots, \mathrm{n}_{\mathrm{i}}$ observations). 
Pairwise Pearson correlations for variables with an absolute value of $|\mathrm{r}| \geq 0.5$ were not included simultaneously in the model development. Indeed, multicollinearity can lead to issues in developing models, such as inaccurate model parameterization, decreased statistical power, and exclusion of significant predictor variables during model construction (Graham, 2003). Only variables with a $P$-value $<0.10$ were retained in the model. We also carried out the ANOVA inflation factor for our best models $(\mathrm{n}=6)$ for the $3 \mathrm{CH}_{4}$ metrics $\left(\mathrm{CH}_{4}\right.$ emissions, g/d per cow; $\mathrm{CH}_{4}$ yield $\mathrm{g} / \mathrm{kg}$ of DMI; and $\mathrm{CH}_{4}$ intensity, $\mathrm{g}$ of $\mathrm{CH}_{4} / \mathrm{kg}$ of milk).

Models associated first with the lowest Bayesian information criterion and then with the lowest root mean square error (RMSE) with the highest coefficient of determination $\left(\mathbf{R}^{2}\right)$ were selected as the best models to predict each $\mathrm{CH}_{4}$ emission response at each level of complexity. Adjusted dependent quantitative variable values were calculated based on regression parameters of the final model for each level of complexity to determine adjusted $\mathrm{R}^{2}$ values corrected for random experiment effect (St-Pierre, 2001).

Prediction error (predicted value minus observed value) was visually inspected for any pattern. Moreover, qualitative factors, $\mathrm{CH}_{4}$ mitigation strategies classified according to Martin et al. (2010), were tested by running ANOVA in R using the "stats" package (version 3.6.0). These mitigation strategies were classified on the basis of forage type (alfalfa, association of different forages, barley, chicory, clover, cocksfoot grass, corn, grass, red clover, and timothy), lipid type represented by major FA from lipid supplementation (C16:0, cis9 C18:1, C18:2n-6, and C18:3n-3), concentrate type (starch rich, sugar rich, lipid rich, and protein rich), or feed additive (nitrate, tannin, saponin, and other plant extracts).

Model Evaluation. The potential of each developed model to accurately predict $\mathrm{CH}_{4}$ production was assessed on 2 independent data sets of individual or mean observations (Figure 1). According to Appuhamy et al. (2016), a combination of model evaluation metrics was used to assess model performance. Briefly, we designate the mean square of prediction error as MSPE and the root of the MSPE as RMSPE, and we also express the RMSPE, as a percentage of the observed mean, as RMSPE\%. Smaller RMSPE\% indicates better model performance. The RMSPE can be decomposed into 3 parts: error due to central tendency or mean bias, error due to deviation of the regression slope or slope bias, and error due to the disturbance or random bias (Bibby and Toutenburg, 1977). The concordance correlation coefficient (CCC; Lin, 1989) was calculated. The CCC is a product of the Pearson correlation coefficient of the relationship between predicted and observed values and the bias correction factor (measure of accuracy) indicating how far the best fit line deviates from the concordance or unity line of the observed values versus predicted values plot. The CCC ranges from 0 to 1 , with greater values indicating better model performance. When using different data to compare the performance of models, we define the RMSPE-to-standard-deviation ratio (RSR) as the RMSPE divided by the standard deviation of the data (observed values), as it takes into account standardized model performance relative to the variability in observations in different data sets (Moriasi et al., 2007). Smaller RSR $(<1)$ indicates better performance given the variability of observations. Model performance was primarily ranked based on RSR, followed by RMSPE\%, and then the other criteria.

\section{RESULTS}

\section{Database}

The individual animal observations contained diets based on 30 to $100 \%$ (\% DM) forages that were pasture, silage, hay, or haylage (alfalfa, barley, corn, timothy, clover, chicory, ray grass, and cocksfoot grass). The experiments included a large variety of dietary strategies with different forage:concentrate ratios, types of concentrate or forage, supplementation of lipids (fat, oil, or FA), plant extracts (essential oils, tannins, and saponins), chemical additives (nitrate), and probiotics (Saccharomyces cerevisiae). The data set based on mean data from the literature included other supplements such as 3-NOP, monensin, or plant extracts (Supplemental Table S2, https://doi.org/10.3168/jds .2018-15940).

Overall, individual data showed a wide range of values of the predictors (e.g., MFA, DMI, milk) and response variables (e.g., $\mathrm{CH}_{4}$ production in $\mathrm{g} / \mathrm{d}, \mathrm{CH}_{4}$ yield in $\mathrm{g} /$ $\mathrm{kg}$ of DMI, and $\mathrm{CH}_{4}$ intensity in $\mathrm{g} / \mathrm{kg}$ of milk), enabling the development of models capable of predicting $\mathrm{CH}_{4}$ emissions across a wide variety of production conditions in dairy cows. Individual MFA were considerably variable, with coefficients of variation $(\mathbf{C V})$ ranging from $20 \%$ to more than $100 \%$ (Tables 1 and 2). The values of $\mathrm{CH}_{4}$ emissions were also variable, with an average CV of $28 \%$. The average DMI and milk yield were $20.5 \mathrm{~kg} / \mathrm{d}$ and $28.6 \mathrm{~kg} / \mathrm{d}$ per cow, respectively. In line with individual animal observations, individual MFA in the external mean data set had large CV. Moreover, the means of DMI and milk yield were similar between individual and mean data sets $(21.0$ and $31.3 \mathrm{~kg} / \mathrm{d}$, respectively). 
Pearson Correlation Coefficients Between $\mathrm{CH}_{4}$ Emissions and Individual MFA

Among individual MFA concentrations, C10:0 and C8:0 had positive relationships with $\mathrm{CH}_{4}$ production ( $\mathrm{r}$ $=0.33$ and 0.35, respectively; $P<0.05$; Supplemental Table S3, https://doi.org/10.3168/jds.2018-15940). The $\mathrm{CH}_{4}$ yield and intensity were positively related to $\mathrm{C} 16: 0$ $(\mathrm{r}=0.24$ and 0.26 , respectively; $P<0.05)$. Production of $\mathrm{CH}_{4}$ was inversely related to iso $\mathrm{C} 17: 0$ (coeluted with trans-9 $\mathrm{C} 16: 1 ; \mathrm{r}=-0.32 ; P<0.05)$. The $\mathrm{CH}_{4}$ yield and intensity had positive relationships with iso C16:0 ( $\mathrm{r}=$ -0.27 and 0.33 , respectively; $P<0.05$ ). Negative correlations between $\mathrm{CH}_{4}$ production, yield, and intensity were observed with cis-10 C18:1, cis-11 C18:1, and cis15 C18:1. However, less than 50\% of the data were reported for cis-10 C18:1 (data not shown). Methane production, yield, and intensity were negatively correlated with trans-10 C18:1 and trans-10+trans-11 C18:1, with Pearson coefficient correlations varying from -0.34 to $-0.45(P<0.05)$; trans-11, cis-15 C18:2 was inversely correlated with $\mathrm{CH}_{4}$ production $(\mathrm{r}=-0.29 ; P<0.05)$, and cis-9,cis-12 C18:2 was negatively correlated with $\mathrm{CH}_{4}$ yield $(\mathrm{r}=-0.30 ; P<0.05)$. All ANOVA inflation factors are $<5$ for the best models developed below.

\section{Mixed-Effect Models}

Models for Daily $\mathrm{CH}_{4}$ Production. Models to predict daily $\mathrm{CH}_{4}$ production are given in Table 3 . Daily $\mathrm{CH}_{4}$ production had positive relationships with C10:0, DMI, NDF, milk yield, milk fat and protein percentages, and BW. There were negative relationships between $\mathrm{CH}_{4}$ production and several MFA, such as iso C17:0 (+trans-9 C16:1), cis-11 C18:1, trans-10 C18:1, and trans-11,cis-15 C18:2. The best simple model included 4 MFA and had an RMSE of $65.1 \mathrm{~g} / \mathrm{d}\left(\mathrm{R}^{2}\right.$ $=0.84 ;$ RMSE $\%=15.7 \%$; Table 3 ). The RSR was 0.86 and 1.12 , CCC was 0.23 and 0.02 , and RMSPE was 22.3 and $25.5 \%$ with the external individual and mean data sets, respectively (equation 1; Table 3). The MFA model's error was mainly associated with error due to disturbance (error due to disturbance $=96 \%$ ) in the evaluation with the external individual data set, whereas with the external mean data set, the error was mainly due to the central tendency $(52 \%)$ as expected.

When DMI was added to the simple model based on MFA, RMSE percentage decreased from $15.7 \%$ to $13.7 \%$ and $\mathrm{R}^{2}$ increased from 0.84 to 0.89 (equation 2; Table 3). We also observed better prediction ability as RSR decreased from 0.86 and 1.13 to 0.76 and 0.90 in the external individual data set and external mean data set used for model evaluations, respectively. Moreover, RMSPE\% decreased from 22.3 to $19.7 \%$ and from 25.5 to $20.3 \%$ with the external individual data set and the external mean data set, respectively. We observed the best performance when DMI, dietary NDF and EE contents, and BW were included along with the MFA (iso $\mathrm{C} 17: 0+$ trans-16 $\mathrm{C} 16: 1$, cis-11 C18:1, and trans11, cis-15 C18:2) in equation $9\left(\mathrm{RMSE}=46.6 \mathrm{~g} / \mathrm{d} ; \mathrm{R}^{2}\right.$ $=0.92)$. The RSR and CCC analysis showed the lowest RSR (0.62) and the greatest CCC (0.73) for equation 9 compared with other models when evaluated on the external mean data set. Consistently, equation 9 was related to the smallest RMSPE when evaluated in both external data sets (18.6 and $14.0 \%$ on external individual and mean data sets, respectively). Error was due to random variability of data as indicated by substantial dispersion error (85.7 and $93.9 \%$ when evaluated on external individual and mean data sets, respectively). The model including all the variables (equation 11) had RSR, RMSPE, and CCC similar to those of equation 9 , indicating that no additional explanatory power was gained from increasing model complexity beyond equation 9.

Models for $\mathrm{CH}_{4}$ Yield. There were positive relationships between $\mathrm{CH}_{4}$ yield and $\mathrm{C} 16: 0$ and iso $\mathrm{C} 16: 0$ but negative relationships between $\mathrm{CH}_{4}$ yield and UFA, such as cis-11 C18:1, trans-10 C18:1, and cis-9,cis-12 C18:2 (equations 12, 13, and 14). The $\mathrm{CH}_{4}$ yield had positive and negative relationships with dietary NDF and EE and milk yield, respectively. The MFA model (equation 12) had an RMSE of $2.8 \mathrm{~g} / \mathrm{kg}$ of DMI (13.9\%) and $R^{2}=0.82$ (Table 4 ). The evaluation resulted in an RSR of 1.13 and 1.00 and a CCC of 0.29 and 0.44 for the external individual data set and external mean data set, respectively. Equation $13\left(\mathrm{RMSE}=2.6 ; \mathrm{R}^{2}=0.85\right)$ based on MFA $(n=5)$ and dietary NDF and EE had the best prediction abilities (Table 4), with lower RSR (1.01 and 0.90) and higher CCC (0.41 and 0.72) in both external evaluation data sets compared with the other models. The RMSPE values were 20.1 and $16.6 \%$ in the external individual data set and external mean data set, respectively. Random error accounted for the biggest part of the total prediction error $(>85 \%)$. When all variables were included (equation 14), the RSR (1.10 and 0.93) were close to those from equation 13, but RMSPE was increased when this equation was evaluated in both external evaluation data sets.

Models for $\mathrm{CH}_{4}$ Intensity. Milk iso C16:0 content was positively related to $\mathrm{CH}_{4}$ intensity, whereas a negative association was found with milk cis-15 C18:1 and trans-10+trans-11 C18:1 contents in equation 15 (Table 5), which had an RMSE of $2.9 \mathrm{~g} / \mathrm{kg}$ of milk $(18.7 \%)$ and $\mathrm{R}^{2}=0.70$. The evaluation of the model in the external individual data set and external mean data set resulted in an RSR of 0.96 and 1.07, CCC of 0.37 and 0.47 , and RMSPE of 38.4 and $26.3 \%$, respec- 


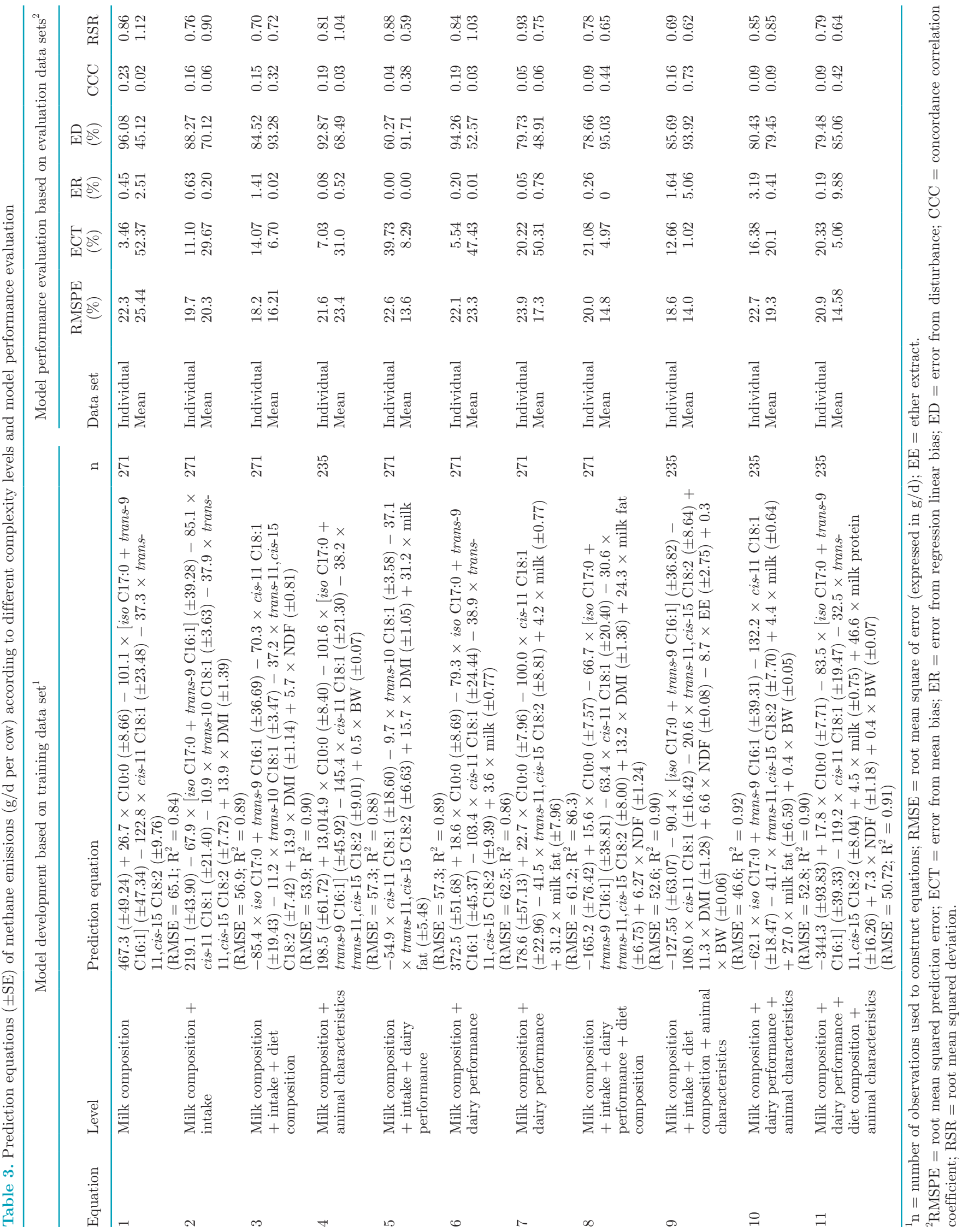




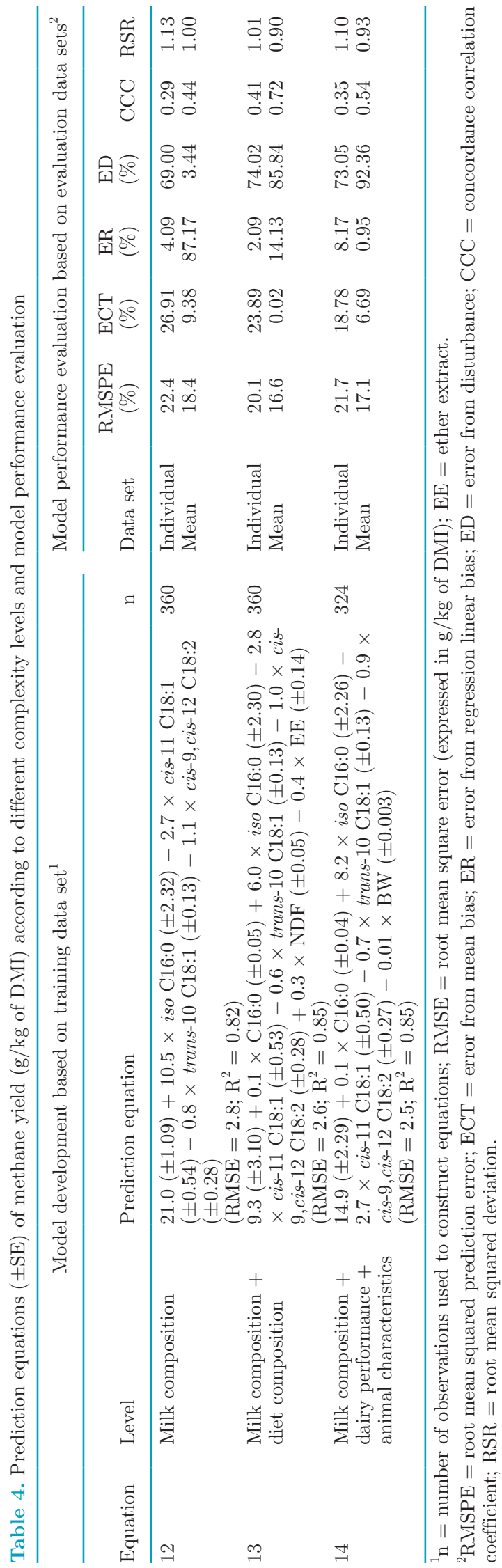

tively. Equation 19 (RMSE $=2.7 \mathrm{~g} / \mathrm{kg}$ of milk; $\mathrm{R}^{2}=$ 0.77; Table 5), based on milk C16:0, iso C16:0, trans-10 C18:1, dietary NDF, and animal characteristics (DIM), had the best prediction abilities with low RSR (0.58 and 0.64) and high CCC (0.82 and 0.84) in both external evaluation data sets compared with the other models. The RMSPE values were 32.7 and $16.7 \%$ when equation 19 was evaluated in the external individual data set and external mean data set, respectively. As already observed for $\mathrm{CH}_{4}$ yield $(\mathrm{g} / \mathrm{kg}$ of $\mathrm{DMI})$, there were positive relationships between $\mathrm{CH}_{4}$ intensity and C16:0, iso C16:0, and NDF, whereas there were negative relationships between $\mathrm{CH}_{4}$ intensity and trans-10 C18:1.

Dietary Strategies Effects. Marginal effects forage type and different feed additives (nitrate, essential oil, saponin, tannin, and other plant extracts) were tested on the residuals of equations 1 and 9 , but no associations were observed $(P>0.05)$. The analysis of residuals indicated that the type of the major FA in lipid-supplemented diets explained a considerable proportion of the residuals of equation $12(P<0.05)$. In addition, several FA (C16:0, cis-9 C18:1, cis-9, cis-12 C18:2, and C18:3n-3) tended to be associated with the residuals of equation $13(P<0.10)$. No effects of the other dietary mitigation strategies were observed on the residuals of $\mathrm{CH}_{4}$ yield prediction equations. Saponin supplementation, specifically tea saponin, tended to have an effect $(P<0.10)$ on MFA model residuals of equation $15(P<0.10)$. No other effect of $\mathrm{CH}_{4}$ mitigation strategies was observed.

\section{DISCUSSION}

The compilation of experiments in the 825 individual data sets used for model development $(\mathrm{n}=568)$ contained a larger variety of diets from experiments conducted across 5 countries in Europe, North America, and Asia-Australia (Supplemental Table S1, https:// doi.org/10.3168/jds.2018-15940) compared with the data used for development of previously reported equations to predict $\mathrm{CH}_{4}$ emissions $(\mathrm{n}=246$ observations in Williams et al., 2014; $\mathrm{n}=218$ observation in van Gastelen et al., 2018).

\section{Key MFA Predictors in Simple Models}

The data set showed a wide range of values in concentrations of individual MFA, with CV ranging from $20 \%$ to more than $100 \%$ (Table 1 ). This wide range in individual MFA concentrations was desirable for predictive purposes because previous meta-analyses have shown that concentrations of individual FA are highly variable (van Lingen et al., 2014). As expected, 
BOUGOUIN ET AL.

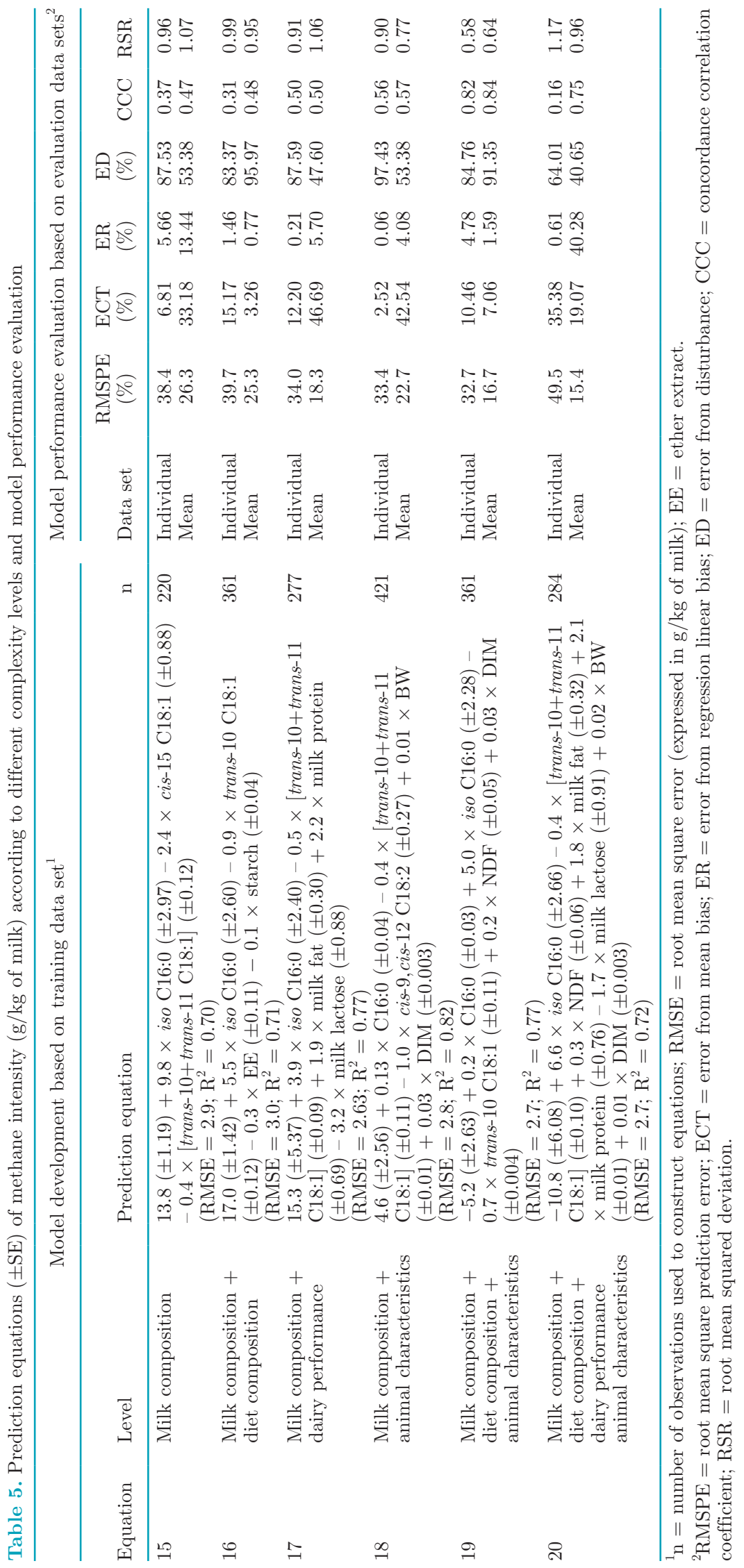


we observed positive relationships between iso $\mathrm{C} 16: 0$ and $\mathrm{CH}_{4}$ yield $(\mathrm{g} / \mathrm{kg}$ of $\mathrm{DMI})$ and intensity $(\mathrm{g} / \mathrm{kg}$ of milk). The relationships between branched-chain FA and $\mathrm{CH}_{4}$ emissions have been reported in several other studies [van Gastelen et al. (2017) and Chilliard et al. (2009) for $\mathrm{CH}_{4}$ production in $\mathrm{g} / \mathrm{d}$; Dijkstra et al. (2011) for $\mathrm{CH}_{4}$ yield in $\mathrm{g} / \mathrm{kg}$ of DMI; van Lingen et al. (2014) for $\mathrm{CH}_{4}$ intensity in $\mathrm{g} / \mathrm{kg}$ of milk]. Indeed, outer membranes of fibrolytic bacteria are rich in branchedchain FA, and more specifically in iso FA (Vlaeminck et al., 2006). Fibrolytic bacteria are in great number in fiber-rich diets, which are known to be linked to high $\mathrm{CH}_{4}$ emissions (Morvan et al., 1996). Vlaeminck et al. (2006) also reported increasing odd-iso FA content in milk from cows fed increasing proportions of forage. Thus, the negative relationship between iso C17:0 (coeluted with trans-9 C16:1) and $\mathrm{CH}_{4}$ production $(\mathrm{g} / \mathrm{d})$ was unexpected. Vlaeminck et al. (2006) also observed greater iso C17:0 content with the inclusion of corn silage or lipid (rich in C18:3 n-3) supplementation in the diet. These dietary strategies (replacing grass silage by corn silage or adding lipids in the diet) are known to lower $\mathrm{CH}_{4}$ emissions in dairy cows (Hristov et al., 2013). We also report negative relationships among milk cis-MUFA (cis-11 C18:1 and cis-15 C18:1), transMUFA (trans-10 C18:1 and trans-10+trans-11 C18:1), and PUFA (trans-11,cis-15 18:2 and cis-9,cis-12 C18:2) and $\mathrm{CH}_{4}$ emissions. Negative associations between milk C18:1, C18:2, and C18:3 isomers and $\mathrm{CH}_{4}$ emissions have also been observed by Chilliard et al. (2009), Dijkstra et al. (2011), van Lingen et al. (2014), Rico et al. (2016), and van Gastelen et al. (2018). Milk FA composition, ruminal metabolism, and ruminal methanogenesis are linked in several ways. For example, biohydrogenation of unsaturated long-chain FA in the rumen uses up to $2.6 \%$ of metabolic hydrogen, thus limiting its availability for $\mathrm{CH}_{4}$ production. Dietary strategies, such as high-concentrate diets, modify the rumen environment $\left(\mathrm{pH}, \mathrm{H}_{2}\right.$ availability, microbial population), resulting in altered MFA composition and reduced $\mathrm{CH}_{4}$ emissions (Martin et al., 2010). These rumen conditions (i.e., lower ruminal $\mathrm{pH}$ ) are often associated with incomplete ruminal biohydrogenation, resulting in production of UFA intermediates that, after absorption from the intestines, are incorporated in milk fat (Ferlay et al., 2017). Diets supplemented with lipids rich in UFA also tend to decrease DMI (Martin et al., 2008) due to lower gut motility of added dietary fats (Bradford et al., 2008). Therefore, lower $\mathrm{CH}_{4}$ emissions can be observed because DMI and $\mathrm{CH}_{4}$ are positively correlated (Hristov et al., 2013).

The RSR (1.0), CCC (0.44), and RMPSE percentage $(18.4 \%)$ values for the simple prediction equation of $\mathrm{CH}_{4}$ yield including only MFA (equation 12) suggest that this equation performed better than those for $\mathrm{CH}_{4}$ production (equation 1) and $\mathrm{CH}_{4}$ intensity (equation 15) on the external mean data set. In contrast, prediction with a simple equation of $\mathrm{CH}_{4}$ emissions (g/d; equation 1) had better performance than those for $\mathrm{CH} 4$ yield (equation 12) and $\mathrm{CH}_{4}$ intensity (equation 15) when evaluated with the external individual data set. The best complex equations for $\mathrm{CH}_{4}$ emissions (equations 9, 13, and 19) had better performance when evaluated with the external mean data set than with the external individual data set. These discrepancies between evaluation performance could be explained by the lower RMSPE percentage and standard deviation of the external mean data set compared with the standard deviation from the external individual data set for $\mathrm{CH}_{4}$ emission (85 vs. $106 \mathrm{~g} / \mathrm{d}, 4.5$ vs. $4.7 \mathrm{~g} / \mathrm{kg}$ of DMI, and 4.7 vs. $5.0 \mathrm{~g} / \mathrm{kg}$ of milk, respectively). In addition, some dietary strategies (monensin or cardanol) are represented only in the external mean data set. This could further explain why equation 1 (based on MFA) had low performance (RMSPE percentage) when challenged against the external mean data set and seems to be unsuitable for diets supplemented with such additives. The performances of evaluation of the models (RSR, RMSPE percentage) are dependent on the domain of validity of the evaluation data sets used (individual or mean), whereas the performances of development of the models (RMSE and $\mathrm{R}^{2}$ ) are dependent on their predictors.

The potential relationships between $\mathrm{CH}_{4}$ and individual MFA have been studied either in individual experiments (Mohammed et al., 2011; Williams et al., 2014; van Gastelen et al., 2017) or in meta-analysis (Dijkstra et al., 2011; van Lingen et al., 2014; Rico et al., 2016; van Gastelen et al., 2018), and predictions have been developed using different individual MFA only as predictors of $\mathrm{CH}_{4}$ emissions. Milk cis-11 C18:1 and trans-10 C18:1 were the only MFA related to $\mathrm{CH}_{4}$ emissions that were found in this study and in several of the aforementioned studies (Dijkstra et al., 2011; Mohammed et al., 2011; Rico et al., 2016; van Gastelen et al., 2018). Thus, few MFA are commonly found among developed prediction equations in this study and in the literature. In addition, performance of these prediction equations is not consistent, meaning that MFA used alone have a limited potential to predict $\mathrm{CH}_{4}$ emissions.

\section{Key Predictors in Complex Models}

Dry matter intake is a key factor of daily $\mathrm{CH}_{4}$ production (Reynolds et al., 2011). A significant positive relationship between DMI and $\mathrm{CH}_{4}$ production demonstrated that increasing DMI led to greater $\mathrm{CH}_{4}$ emissions because of greater availability of substrates for 
microbial fermentation in the rumen (Niu et al., 2018). Equation 2 further verified that DMI is a major driver of enteric $\mathrm{CH}_{4}$ production in dairy cows and thus is a strong predictor of $\mathrm{CH}_{4}$ emissions (Hristov et al., 2013).

Dietary NDF, which represents the effect of forage inclusion rates, was included as a positive predictor in several equations showing the best performance (equations 9, 13, and 19) for all $3 \mathrm{CH}_{4}$ emission responses. Studies focusing on the effect of types of carbohydrates have indicated that diets rich in NDF generally promote high acetate and butyrate production and, in turn, high $\mathrm{CH}_{4}$ emissions (Moe and Tyrrell, 1979; Johnson and Johnson, 1995; Bannink et al., 2008; Bougouin et al., 2018). On the other hand, nonstructural carbohydrates, primarily starch, favor production of propionate, resulting in less $\mathrm{CH}_{4}$ production in the rumen. Additionally, it has been shown that substituting wheat, which is rapidly fermented in the rumen, in place of pasture, which is rich in structural carbohydrates, in the diet reduced $\mathrm{CH}_{4}$ production and yield in dairy cows with no negative effect on milk production, although feeding high levels (i.e., $>40 \%$ of DMI) of wheat decreased milk fat content (Williams et al., 2013; Moate et al., 2014).

Regardless of the $\mathrm{CH}_{4}$ emission response, dietary EE content was also identified as a key negative predictor variable in the best-performing equations. Dietary EE is indicative of the total lipid content in the diet, and the lipid-mitigating effect on enteric $\mathrm{CH}_{4}$ production is well established (Beauchemin et al., 2008; Eugène et al., 2008; Martin, et al., 2010; Knapp et al., 2014). Increased dietary lipid content likely results in low availability of substrate for fermentation in the rumen as lipids are often supplemented at the expense of carbohydrates in the diet. Moreover, lipids can have a toxic effect on methanogens and on protozoa known to produce a great amount of $\mathrm{H}_{2}$ that promotes $\mathrm{CH}_{4}$ production in the rumen (Grainger and Beauchemin, 2011; Guyader et al., 2014). Consistently, dietary EE in all of the equations was significantly and negatively correlated with $\mathrm{CH}_{4}$ emissions. Several prediction equations developed in the literature have also included $\mathrm{EE}$ as a negative predictor of $\mathrm{CH}_{4}$ emissions but with different effect size (regression coefficient) estimates. Indeed, Moate et al. (2011) conducted a meta-analysis using 17 experiments and developed a $\mathrm{CH}_{4}$ yield prediction equation with a coefficient of -0.08 per unit increase in dietary EE content (12 to $114 \mathrm{~g} / \mathrm{kg}$ of DM). Grainger and Beauchemin (2011) also proposed a prediction equation for $\mathrm{CH}_{4}$ yield, developed with lactating cows fed 44 dietary treatments, with a coefficient of -0.1 per unit of dietary EE (\% of DM). In the present study, the coefficient for dietary EE content was -0.4 for equation 13 using $\mathrm{EE}$ as a predictor of $\mathrm{CH}_{4}$ yield. However, a similar coefficient for dietary EE (from -0.29 to -0.45 ) was found in intercontinental prediction equations for $\mathrm{CH}_{4}$ yield developed by Niu et al. (2018). Additional factors were considered in our study, and the size and consistency of the data sets differed compared with the studies of Moate et al. (2011) and Grainger and Beauchemin (2011); this could explain the difference of slopes observed in this study, because they explain another part of the variability not taken into account with EE alone.

Body weight was positively related to $\mathrm{CH}$ production and intensity as reported in a prediction equation developed by Niu et al. (2018). As mentioned by Hristov et al. (2013), BW and DMI are positively related to each other, which led to more rumen feed fermentation, resulting in greater $\mathrm{CH}_{4}$ production.

Complex equations developed in this study exhibited better performance when the above-stated variables were added to the simple equations including only MFA in predicting $\mathrm{CH}_{4}$ production (RMSE $=46.6$ vs. $65.1 \mathrm{~g} / \mathrm{d} ; \mathrm{R}^{2}=0.92$ and 0.84 , respectively), $\mathrm{CH}_{4}$ yield $\left(\mathrm{RMSE}=2.6\right.$ vs. $2.8 \mathrm{~g} / \mathrm{kg}$ of DMI; $\mathrm{R}^{2}=0.85$ and 0.82 , respectively), or $\mathrm{CH}_{4}$ intensity ( $\mathrm{RMSE}=2.7$ vs. $2.9 \mathrm{~g} /$ $\mathrm{kg}$ of milk; $\mathrm{R}^{2}=0.77$ and 0.70 , respectively). Moreover, we observed that accuracy of prediction of $\mathrm{CH}_{4}$ production improved $(\mathrm{RSR}=0.69$ and $0.62 ;-4 \%$ RMSPE with the external individual data set; $-11 \%$ RMSPE with the external mean data set) when the independent variables (e.g., DMI, dietary NDF and EE, DIM, and BW) were added to the equation based on MFA. Our results confirm that increasing the complexity of predicting equations leads to better goodness of fit most of the time (Moraes et al., 2014; Santiago-Juarez et al., 2016; Niu et al., 2018), probably because more complex equations explain an additional proportion of the variability not taken into account in simple equations with MFA alone.

The ability of equations to predict $\mathrm{CH}_{4}$ emissions is increased when other variables (intake, diet composition, or BW) are included along with MFA, probably because they explain another part of the variability not taken into account with MFA alone. In that sense, dietary FA would be a variable of interest to increase a model's ability to predict $\mathrm{CH}_{4}$ emissions. We were not able to include dietary FA in our analysis because very few data were available, but future studies should take it into account for model development.

\section{Effects of Qualitative Factors on Prediction Equation Residuals}

When the class of lipids, forage type, and different feed additives were further tested on the prediction error, no further marginal effects were observed for $\mathrm{CH}_{4}$ production. We only observed an effect of the major FA 
supplemented on the residuals for $\mathrm{CH}_{4}$ yield in equation 12. The major FA responsible for this effect was $\mathrm{C} 18$ : 3n-3, compared with cis-9 C18:1, and led to a decrease of the intercept in equation 12 . This result is in line with Doreau et al. (2011), who also observed an effect of the lipid class on the slope of the overall relationship between $\mathrm{CH}_{4}$ yield and EE. Conversely, Grainger and Beauchemin (2011) did not observe such an effect in their meta-analysis. This discrepancy, which occurred across different studies, could be due to the variability in composition of the database. Indeed, not all the studies that focused on the effect of lipid class on $\mathrm{CH}_{4}$ emission were included in our data set that was used to develop the equations. In this study, saponin or essential oil had an effect on the residuals of the $\mathrm{CH}_{4}$ intensity prediction equation, but we cannot draw conclusions on the effect of the type of these additives because only tea saponin and 2 types of essential oil were present in the database.

Furthermore, measurement of $\mathrm{CH}_{4}$ emissions, even when done using the gold standard methods, unavoidably includes several associated errors because these techniques need to be correctly and appropriately used to generate reliable and accurate data (Hristov et al., 2018). In addition, even when cows are fed a fixed amount of a specific diet for a period of up to $16 \mathrm{wk}$, there may be substantial changes over time in $\mathrm{CH}_{4}$ emissions, probably associated with adaption of ruminal microbial populations (Moate et al., 2018). Thus, these issues continue to present challenges for the development of models that can accurately predict $\mathrm{CH}_{4}$ production, yield, and intensity.

\section{Application of $\mathrm{CH}_{4}$ Prediction Equations on Farm}

The best $\mathrm{CH}_{4}$ prediction equation developed in this study has a low potential of applicability on farm. Indeed, milk samples could be routinely obtained on farm, but the GC technique, which is the gold standard method to determine MFA, is rather expensive and time consuming. Moreover, research has been directed toward the use of near-infrared reflectance or mid-infrared (MIR) spectrometry, which are rapid, less expensive, and easier methods to determine MFA concentrations. Furthermore, MIR spectrometry is already implemented in laboratories of milk recording organizations, in France and Belgium for instance, to quantify major milk components used for milk payment and can be used to estimate various MFA, such as C12:0, C14:0, C16:0, cis-9 C16:1, and cis-9 C18:1, and SFA and MUFA in cow milk (Soyeurt et al., 2006).

Unfortunately, the best 5 MFA predictors of $\mathrm{CH}_{4}$ emissions reported in the current study are not all well quantified with MIR spectrometry, except for C8:0,
C10:0, C16:0, and cis-11 C18:1 (Soyeurt et al., 2006; Ferrand-Calmels et al., 2014). Thus, for on-farm estimation of $\mathrm{CH}_{4}$ emissions (yield and intensity) in the near future, the MIR spectrometry technique should evolve to accurately estimate the key MFA used in the $\mathrm{CH}_{4}$ prediction equations developed in this study.

\section{CONCLUSIONS}

Our analysis, based on a relatively large data set including a wide range of diets from 5 countries, indicated that MFA have better potential to accurately predict enteric $\mathrm{CH}_{4}$ production, yield, and intensity of dairy cows when combined with other variables (e.g., DMI) compared with on their own. Equations based only on MFA performed well, with RMSPE percentage ranging from 18 to $38 \%$. Inclusion of DMI, dietary NDF, EE, DIM, and BW in the equation further improved prediction performance, with RMSPE percentage ranging from 14 to $32 \%$ for the best ones. Nevertheless, DMI is difficult to measure routinely in commercial farms.

\section{ACKNOWLEDGMENTS}

This study is part of a collaborative project led by INRA and funded by 11 institutes and private companies: Adisseo France SAS (Antony, France), Agrial (Caen, France), APIS-GENE (Paris, France), Deltavit (Janzé, France), DSM Nutritional Products AG (Kaiseraugst, Switzerland), Institut de l'Elevage (Paris, France), Lallemand (Blagnac, France), Moy Park Beef Orléans (Fleury-les-Aubrais, France), Neovia (SaintNolff, France), Techna France Nutrition (Couëron, France), and Valorex (Combourtillé, France). All authors read and approved the final manuscript. The authors declare that they have no competing interests.

\section{REFERENCES}

Appuhamy, J. A. D. R. N., J. France, and E. Kebreab. 2016. Models for predicting enteric methane emissions from dairy cows in North America, Europe, and Australia and New Zealand. Glob. Chang. Biol. 22:3039-3056.

Bannink, A., J. France, S. Lopez, W. J. J. Gerrits, E. Kebreab, S. Tamminga, and J. Dijkstra. 2008. Modelling the implications of feeding strategy on rumen fermentation and functioning of the rumen wall. Anim. Feed Sci. Technol. 143:3-26.

Beauchemin, K., M. Kreuzer, F. O'Mara, and T. McAllister. 2008. Nutritional management for enteric methane abatement: A review. Anim. Prod. Sci. 48:21-27.

Bibby, J., and T. Toutenburg. 1977. Prediction and Improved Estimation in Linear Models. Wiley, Chichester, UK.

Bougouin, A., A. Ferlay, M. Doreau, and C. Martin. 2018. Effects of carbohydrate type or bicarbonate addition to grass silage-based diets on enteric methane emissions, milk production, and fatty acid composition in dairy cows. J. Dairy Sci. 101:6085-6097.

Bradford, B. J., K. J. Harvatine, and M. S. Allen. 2008. Dietary unsaturated fatty acids increase plasma glucagon-like peptide- 1 and 
cholecystokinin and may decrease premeal ghrelin in lactating dairy cows. J. Dairy Sci. 91:1443-1450.

Chilliard, Y., C. Martin, J. Rouel, and M. Doreau. 2009. Milk fatty acids in dairy cows fed whole crude linseed, extruded linseed, or linseed oil, and their relationship with methane output. J. Dairy Sci. 92:5199-5211.

Dijkstra, J., S. M. Van Zijderveld, J. A. Apajalahti, A. Bannink, W. J. J. Gerrits, J. R. Newbold, H. B. Perdok, and H. Berends. 2011. Relationships between methane production and milk fatty acid profiles in dairy cattle. Anim. Feed Sci. Technol. 166-167:590-595.

Doreau, M., C. Martin, M. Eugène, M. Popova, and D. P. Morgavi. 2011. Leviers d'action pour réduire la production de méthane entérique par les ruminants. Prod. Anim. 24:461.

Eugène, M., D. Masse, J. Chiquette, and C. Benchaar. 2008. Metaanalysis on the effects of lipid supplementation on methane production in lactating dairy cows. Can. J. Anim. Sci. 88:331-334.

FAO. 2013. Livestock and the environment. Accessed Jun. 12, 2018. http://www.fao.org/livestock-environment/en/.

Ferlay, A., L. Bernard, A. Meynadier, and C. Malpuech-Brugère. 2017. Production of trans and conjugated fatty acids in dairy ruminants and their putative effects on human health: A review. Biochimie 141:107-120.

Ferrand-Calmels, M., I. Palhiére, M. Brochard, O. Leray, J. M. Astruc, M. R. Aurel, S. Barbey, F. Bouvier, P. Brunschwig, H. Caillat, M. Douguet, F. Faucon-Lahalle, M. Gelé, G. Thomas, J. M. Trommenschlager, and H. Larroque. 2014. Prediction of fatty acid profiles in cow, ewe, and goat milk by mid-infrared spectrometry. J. Dairy Sci. 97:17-35.

Gerber, P. J., H. Steinfeld, B. Henderson, A. Mottet, C. Opio, J. Dijkman, A. Falcucci, and G. Tempio. 2013. Tackling Climate Change through Livestock: A Global Assessment of Emissions and Mitigation Opportunities. Food and Agriculture Organization of the United Nations, Rome, Italy.

Graham, M. H. 2003. Confronting multicollinearity in ecological multiple regression. Ecology 84:2809-2815.

Grainger, C., and K. A. Beauchemin. 2011. Can enteric methane emissions from ruminants be lowered without lowering their production? Anim. Feed Sci. Technol. 166-167:308-320.

Guyader, J., M. Eugène, P. Nozière, D. P. Morgavi, M. Doreau, and C. Martin. 2014. Influence of rumen protozoa on methane emissions in ruminants: A meta-analysis approach. Animal 8:1816-1825.

Hristov, A. N., E. Kebreab, M. Niu, J. Oh, A. Bannink, A. R. Bayat, T. B. Boland, A. F. Brito, D. P. Casper, L. A. Crompton, J. Dijkstra, M. Eugene, P. C. Garnsworthy, N. Haque, A. L. F. Hellwing, P. Huhtanen, M. Kreuzer, B. Kuhla, P. Lund, J. Madsen, C. Martin, P. J. Moate, S. Muetzel, C. Munoz, N. Peiren, M. Powell, C. K. Reynolds, A. Schwarm, K. J. Shingfield, T. M. Storlien, M. R. Weisbjerg, D. R. Yanez-Ruiz, and Z. Yu. 2018. Symposium review: Uncertainties in enteric methane inventories, measurement techniques, and prediction models. J. Dairy Sci. 101:6655-6674.

Hristov, A. N., J. Oh, C. Lee, R. Meinen, F. Montes, T. Ott, and S. Oosting. 2013. Mitigation of greenhouse gas emissions in livestock production-A review of technical options for non- $\mathrm{CO}_{2}$ emissions. FAO Animal Production and Health Paper No. 177. Food and Agriculture Organization of the United Nations, Rome, Italy.

INRA (Institut National de la Recherche Agronomique). 2007. Alimentation des bovins ovins et caprins. Besoins des animaux - Valeurs des aliments-Tables INRA 2007. Editions Quae, Versailles, Paris.

IPCC (Intergovernmental Panel on Climate Change). 2007. Climate Change 2007: Synthesis Report. Contribution of Working Groups I, II and III to the Fourth Assessment Report of the Intergovernmental Panel on Climate Change. IPCC, Geneva, Switzerland.

Johnson, K. A., and D. E. Johnson. 1995. Methane emissions from cattle. J. Anim. Sci. 73:2483-2492.

Knapp, J. R., G. L. Laur, P. A. Vadas, W. P. Weiss, and J. M. Tricarico. 2014. Invited review: Enteric methane in dairy cattle production: Quantifying the opportunities and impact of reducing emissions. J. Dairy Sci. 97:3231-3261.

Lin, L. I. K. 1989. A concordance correlation coefficient to evaluate reproducibility. Biometrics 45:255-268.
Lindstrom, M. L., and D. M. Bates. 1990. Nonlinear mixed effects models for repeated measures data. Biometrics 46:673-687.

Martin, C., D. P. Morgavi, and M. Doreau. 2010. Methane mitigation in ruminants: From microbe to the farm scale. Animal 4:351-365.

Martin, C., J. Rouel, J. P. Jouany, M. Doreau, and Y. Chilliard. 2008. Methane output and diet digestibility in response to feeding dairy cows crude linseed, extruded linseed, or linseed oil. J. Anim. Sci. $86: 2642-2650$

Mills, J. A., J. Dijkstra, A. Bannink, S. B. Cammell, E. Kebreab, and J. France. 2001. A mechanistic model of whole-tract digestion and methanogenesis in the lactating dairy cow: Model development, evaluation, and application. J. Anim. Sci. 79:1584-1597.

Moate, P. J., J. L. Jacobs, M. C. Hannah, G. L. Morris, K. A. Beauchemin, P. S. Alvarez-Hess, P. J. Eckard, Z. Liu, S. Rochfort, W. J. Wales, and S. R. O. Williams. 2018. Adaptation responses in milk fat yield and methane emissions of dairy cows when wheat was included in their diet for 16 weeks. J. Dairy Sci. 101:7117-7132.

Moate, P. J., S. R. O. Williams, M. H. Deighton, W. J. Wales, and J. L. Jacobs. 2014. Supplementary feeding of wheat to cows fed harvested pasture increases milk production and reduces methane yield. Pages 176-178 in Proc. 6th Australasian Dairy Science Symposium, Hamilton, New Zealand. Australasian Dairy Science Symposium Committee, Hamilton, New Zealand.

Moate, P. J., S. R. O. Williams, C. Grainger, M. C. Hannah, E. N. Ponnampalam, and R. J. Eckard. 2011. Influence of cold-pressed canola, brewers grains and hominy meal as dietary supplements suitable for reducing enteric methane emissions from lactating dairy cows. Anim. Feed Sci. Technol. 166-167:254-264.

Moe, P. W., and H. F. Tyrrell. 1979. Methane production in dairy cows. J. Dairy Sci. 62:1583-1586.

Mohammed, R., S. McGinn, and K. Beauchemin. 2011. Prediction of enteric methane output from milk fatty acid concentrations and rumen fermentation parameters in dairy cows fed sunflower, flax, or canola seeds. J. Dairy Sci. 94:6057-6068.

Moraes, L. E., A. B. Strathe, J. G. Fadel, D. P. Casper, and E. Kebreab. 2014. Prediction of enteric methane emissions from cattle. Glob. Change Biol. 20:2140-2148.

Moriasi, D. N., J. G. Arnold, M. W. Van Liew, R. L. Bingner, R. D. Harmel, and T. L. Veith. 2007. Model evaluation guidelines for systematic quantification of accuracy in watershed simulations. Trans. ASABE 50:885-900.

Morvan, B., F. Bonnemoy, G. Fonty, and P. Gouet. 1996. Quantitative determination of $\mathrm{H} 2$-utilizing acetogenic and sulfate-reducing bacteria and methanogenic archaea from digestive tract of different mammals. Curr. Microbiol. 32:129-133.

Niu, M., E. Kebreab, A. N. Hristov, J. Oh, C. Arndt, A. Bannink, A. R. Bayat, A. F. Brito, T. Boland, D. Casper, L. A. Crompton, J. Dijkstra, M. Eugene, P. C. Garnsworthy, M. N. Haque, A. L. F. Hellwing, P. Huhtanen, M. Kreuzer, B. Kuhla, P. Lund, J. Madsen, C. Martin, S. C. McClelland, M. McGee, P. J. Moate, S. Muetzel, C. Munoz, P. O'Kiely, N. Peiren, C. K. Reynolds, A. Schwarm, K. J. Shingfield, T. M. Storlien, M. R. Weisbjerg, D. R. Yanez-Ruiz, and Z. Yu. 2018. Prediction of enteric methane production, yield, and intensity in dairy cattle using an intercontinental database. Glob. Change Biol. 24:3368-3389.

NRC. 2001. Nutrient Requirements of Dairy Cattle. 7th rev. ed. National Academy Press, Washington, DC.

Odongo, N. E., R. Bagg, G. Vessie, P. Dick, M. M. Or-Rashid, S. E Hook, J. T. Gray, E. Kebreab, J. France, and B. W. McBride. 2007. Long-term effects of feeding monensin on methane production in lactating dairy cows. J. Dairy Sci. 90:1781-1788.

Pyle, D. 1999. Data Preparation for Data Mining. Morgan Kaufmann, Burlington, MA.

Reynolds, C. K., L. A. Crompton, and J. A. N. Mills. 2011. Improving the efficiency of energy utilization in cattle. Anim. Prod. Sci. 51:6-12.

Rico, D. E., P. Y. Chouinard, F. Hassanat, C. Benchaar, and R. Gervais. 2016. Prediction of enteric methane emissions from Holstein dairy cows fed various forage sources. Animal 10:203-211. 
Santiago-Juarez, B., L. E. Moraes, J. A. D. R. N. Appuhamy, W. F. Pellikaan, D. P. Casper, J. Tricarico, and E. Kebreab. 2016. Prediction and evaluation of enteric methane emissions from lactating dairy cows using different levels of covariate information. Anim. Prod. Sci. 56:557-564.

Soyeurt, H., P. Dardenne, G. Lognay, D. Veselko, P. Mayeres, and N. Gengler. 2006. Estimating fatty acid content in cow milk using mid-infrared spectrometry. J. Dairy Sci. 89:3690-3695.

St-Pierre, N. R. 2001. Invited review: Integrating quantitative findings from multiple studies using mixed model methodology. J. Dairy Sci. 84:741-755.

van Gastelen, S., E. C. Antunes-Fernandes, K. A. Hettinga, and J. Dijkstra. 2017. Relationships between methane emission of Holstein Friesian dairy cows and fatty acids, volatile metabolites and nonvolatile metabolites in milk. Animal 11:1539-1548.

van Gastelen, S., and J. Dijkstra. 2016. Prediction of methane emission from lactating dairy cows using milk fatty acids and midinfrared spectroscopy. J. Sci. Food Agric. 96:3963-3968.

van Gastelen, S., H. Mollenhorst, E. C. Antunes-Fernandes, K. A. Hettinga, G. G. van Burgsteden, J. Dijkstra, and J. L. W. Rademaker.
2018. Predicting enteric methane emission of dairy cows with milk Fourier-transform infrared spectra and gas chromatography-based milk fatty acid profiles. J. Dairy Sci. 101:5582-5598.

van Lingen, H. J., L. A. Crompton, W. H. Hendriks, C. K. Reynolds, and J. Dijkstra. 2014. Meta-analysis of relationships between enteric methane yield and milk fatty acid profile in dairy cattle. J. Dairy Sci. 97:7115-7132.

Vlaeminck, B., V. Fievez, A. R. J. Cabrita, A. J. M. Fonseca, and R. J. Dewhurst. 2006. Factors affecting odd- and branched-chain fatty acids in milk: A review. Anim. Feed Sci. Technol. 131:389-417.

Weill, P., N. Kerhoas, G. Chesneau, B. Schmitt, P. Legrand, and J. P. Rennaud. 2008. Nutr. Clin. Metab. 21:S71-S72.

Williams, S. R. O.. T. Clarke, M. C. Hannah, L. C. Marett, P. J. Moate, M. J. Auldist, and B. Wales. 2013. Energy partitioning in herbage-fed dairy cows offered supplementary grain during an extended lactation. J. Dairy Sci. 96:484-494.

Williams, S. R. O., P. J. Moate, M. H. Deighton, M. C. Hannah, and W. J. Wales. 2014. Methane emissions of dairy cows cannot be predicted by the concentrations of C8:0 and total C18 fatty acids in milk. Anim. Prod. Sci. 54:1757-1761. 